\title{
The Potential of Silver Nanoparticles for Antiviral and Antibacterial Applications: A Mechanism of Action
}

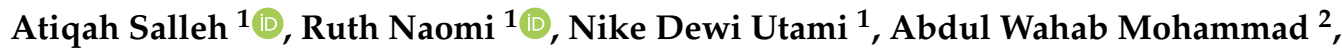 \\ Ebrahim Mahmoudi ${ }^{2}$, Norlaila Mustafa ${ }^{3}(\mathbb{D})$ and Mh Busra Fauzi ${ }^{1, *(1)}$ \\ 1 Centre for Tissue Engineering \& Regenerative Medicine, Faculty of Medicine, Universiti Kebangsaan \\ Malaysia, Kuala Lumpur 56000, Malaysia; atqhsalleh@gmail.com (A.S.); ruthmanuel2104@gmail.com (R.N.); \\ nike.dewiutami@gmail.com (N.D.U.) \\ 2 Department of Chemical and Process Engineering, Faculty of Engineering and Built Environment, Universiti \\ Kebangsaan Malaysia, Bangi 43600, Malaysia; awm.ukm@gmail.com (A.W.M.); ebi.dream@gmail.com (E.M.) \\ 3 Department of Internal Medicine, Universiti Kebangsaan Malaysia Medical Centre (UKMMC), Kuala \\ Lumpur 56000, Malaysia; norlaila@ppukm.ukm.edu.my \\ * Correspondence: fauzibusra@ukm.edu.my
}

Received: 8 July 2020; Accepted: 18 July 2020; Published: 9 August 2020

\begin{abstract}
Rapid development of nanotechnology has been in high demand, especially for silver nanoparticles (AgNPs) since they have been proven to be useful in various fields such as medicine, textiles, and household appliances. AgNPs are very important because of their unique physicochemical and antimicrobial properties, with a myriad of activities that are applicable in various fields, including wound care management. This review aimed to elucidate the underlying mechanisms of AgNPs that are responsible for their antiviral properties and their antibacterial activity towards the microorganisms. AgNPs can be synthesized through three different methods-physical, chemical, and biological synthesis—as indicated in this review. The applications and limitations of the AgNPs such as their cytotoxicity towards humans and the environment, will be discussed. Based on the literature search obtained, the properties of AgNPs scrutinizing the antibacterial or antiviral effect shown different interaction towards bacteria which dependent on the synthesis processes followed by the morphological structure of AgNPs.
\end{abstract}

Keywords: silver nanoparticles; antimicrobials; mechanism of action; antiviral; cytotoxicity; nanotechnology

\section{Introduction}

Silver (Ag) is a chemical element that has provided promising results in various fields such as medicine, electronics, and household applications, e.g., silver sulfadiazine has been used as a standard treatment for burn wounds to prevent the formation of biofilm on the wound area, thus enhancing the wound recovery progress [1]. Silver is a part of transition metals and has been classified as a precious metal due to its decreasing availability. Silver has interesting properties, yet the uses of the materials are limited due to silver instability towards oxygen [2]. Silver metal will oxidize spontaneously when exposed to free oxygen molecules. In these past few years, there has been an unprecedented rise in the application of nanoscience and nanotechnologies which lead to substantial progress in the production of nanomaterials. Thus, it had made possible to produce silver in nanoscale and these emerging nanoparticle products have attracted interest due to their physical, chemical, and biological properties in comparison with their macro-scaled counterparts [3]. These properties are being assessed through various analytical techniques.

Evaluation of silver nanoparticles (AgNPs) involves various types of analytical techniques which includes X-ray diffractometry (XRD) at wavelength $(\lambda)=1.54056 \AA$, X-ray photoelectron spectroscopy 
(XPS) usually between 300-400 eV, Fourier transform infrared spectroscopy (FTIR) in wavelength range of 400-4000 $\mathrm{cm}^{-1}$, ultraviolet visible spectroscopy (UV-vis spectroscopy) at the range of 400-500 nm, transmission electron microscopy (TEM), scanning electron microscopy (SEM), dynamic light scattering (DLS) at scattering angle of $173^{\circ}$, and localized surface plasma resonance (LSPR) at wavelength of $300 \mathrm{~nm}$ to $1100 \mathrm{~nm}$ [4]. These analyses are important to assess the behavior, bio-distribution, and reactivity of these fabricated nanoparticles. Table 1 shows the basic functions of the analytical techniques used for the characterization of AgNPs. However, the result of these analytical techniques depends on the synthesis of AgNPs which also alter the physicochemical properties of the nanoparticles [5]. Recently, experiments with AgNPs have been conducted extensively due to their greater chemical, physical, and biological features compared to their bulk counterparts, such as their size, composition, crystallinity, shape, and structure.

Table 1. Analytical techniques and their basic functions in the characterization of silver nanoparticles.

\begin{tabular}{|c|c|c|}
\hline $\begin{array}{l}\text { Analytical } \\
\text { Technique }\end{array}$ & Functions & References \\
\hline X-ray diffraction & $\begin{array}{l}\text { Measure the degree of crystallinity at the atomic scale. Used to analyze } \\
\text { the structure of nanoparticles, particle sizes, for compounds } \\
\text { identification, and to determine structure imperfections in the structures. } \\
\text { The analysis depends on the formation of diffraction patterns }\end{array}$ & [6] \\
\hline $\begin{array}{l}\text { X-ray photoelectron } \\
\text { spectroscopy }\end{array}$ & $\begin{array}{l}\text { Determine the electronic states by atoms which include the oxidation } \\
\text { state, and electron transfer in the nanoparticles. Estimate the empirical } \\
\text { formulae by surface chemical analysis. } \\
\text { Characterize the nanoparticles' surface in the liquid forms. }\end{array}$ & [7] \\
\hline $\begin{array}{l}\text { Fourier transform } \\
\text { infrared } \\
\text { spectroscopy }\end{array}$ & Characterize various chemical bonding in nanomaterials. & [8] \\
\hline $\begin{array}{l}\text { UV-vis } \\
\text { spectroscopy }\end{array}$ & $\begin{array}{c}\text { Evaluate the stability and characteristics of AgNPs. Absorption of } \\
\text { AgNPs depends on the dielectric medium, particle size, and the } \\
\text { chemical environment. Size depends on surface plasmon for metal } \\
\text { nanoparticles ranging from } 2 \text { to } 100 \mathrm{~nm} \text {. }\end{array}$ & [9] \\
\hline $\begin{array}{l}\text { Transmission } \\
\text { electron microscopy }\end{array}$ & $\begin{array}{c}\text { Measure of particle size, morphology, and size distribution. Provide } \\
\text { better spatial resolution compared to SEM. }\end{array}$ & [10] \\
\hline $\begin{array}{l}\text { Scanning electron } \\
\text { microscopy }\end{array}$ & $\begin{array}{l}\text { Evaluate the morphology of AgNPs. Histogram obtains from images. } \\
\text { Manually measure and count the particles or using specific software. }\end{array}$ & [11] \\
\hline $\begin{array}{l}\text { Dynamic light } \\
\text { scattering }\end{array}$ & $\begin{array}{l}\text { Measure nanoparticles size. Evaluate their stability over time in } \\
\text { suspension at different } \mathrm{pH} \text { and temperature conditions. }\end{array}$ & [12] \\
\hline $\begin{array}{l}\text { Localized surface } \\
\text { plasmon resonance }\end{array}$ & $\begin{array}{l}\text { Determine spatial oscillation of non-excited or excited (near-visible } \\
\text { light) electron. Evaluate the molecular interaction on the surface of a } \\
\text { nanoparticle. Depends on several factors: particle's size and shape, } \\
\text { electronic properties, dielectric media, and temperature }\end{array}$ & [13] \\
\hline
\end{tabular}

The size, morphology, surface, and particle distribution of nanoparticles have proven to influence the physicochemical properties of AgNPs which can be altered through various synthesis methods, reducing agents, and stabilizers [14]. Size has been the determining factor of biological properties of AgNPs and can be adjusted according to specific application typically in the range from $2 \mathrm{~nm}$ until $100 \mathrm{~nm}$ e.g., the size of AgNPs for drug delivery application need to be greater than $100 \mathrm{~nm}$ to accommodate for the quantity of the drug to be delivered [15]. The toxicity of AgNPs is also dependent on the size of the nanoparticles: the smaller the particles, the higher the toxicity due the higher reactivity and ion release in cells [16]. The shape of an AgNP also influences the toxicity as it can be applied in various types of nanostructures such as nanoplates, nanospheres, nanorods, and flower-like nanoparticles [17]. Moreover, AgNPs are used in antimicrobial applications with proven antimicrobial 
characteristics of Ag+ ions. These exceptional properties of AgNPs have enabled their use in the fields of nanomedicine, pharmacy, biosensing, and biomedical engineering.

Silver nanoparticles (AgNPs) are already in high demand in various fields which includ health care, medical, and industrial purposes, due to their unique physical and chemical properties. Their unique properties have been influenced by their surface-to-volume ratio which enables modification of their physical, chemical, and biological properties [18]. AgNPs can be synthesized in different types of media-the liquid with different colloidal shapes, and infused into solid materials. The most intriguing properties of AgNPs is their biological activity which influenced by the size distribution, surface chemistry, particle morphology, chemical composition, agglomeration, capping agent, particle response in media, ion release, and the reducing agents used during AgNP synthesis [19]. Understanding the physicochemical properties of AgNPs is crucial as it affects the cellular uptake, infiltration into biological membrane or barriers, the particles distribution, and the therapeutic effects. Therefore, the development of AgNPs that are uniform in morphology and functionality is important for various applications.

Additional insights into the characteristics of AgNPs are discussed in this review. This review presents comprehensive and detailed information on the synthesis of AgNPs by various methods as well as the antibacterial of a AgNP. In addition, the review also focuses on the antiviral effect, application, safety, and limitation of AgNPs.

\section{Synthesis of AgNPs}

There are various methods that have been done to synthesize silver nanoparticles (AgNPs) consist of physical, chemical, and biological methods which is also known as green synthesis. Figure 1 shows the simple graphic diagram of the AgNP synthesis overview. Generally, AgNP syntheses are classified as "top-down" and "bottom-up" method. The top-down method is basically the physical method consisting of mechanically grinding the silver bulks while the bottom-up methods consist of chemical reduction, sono-decomposition, and electrochemical methods [20].

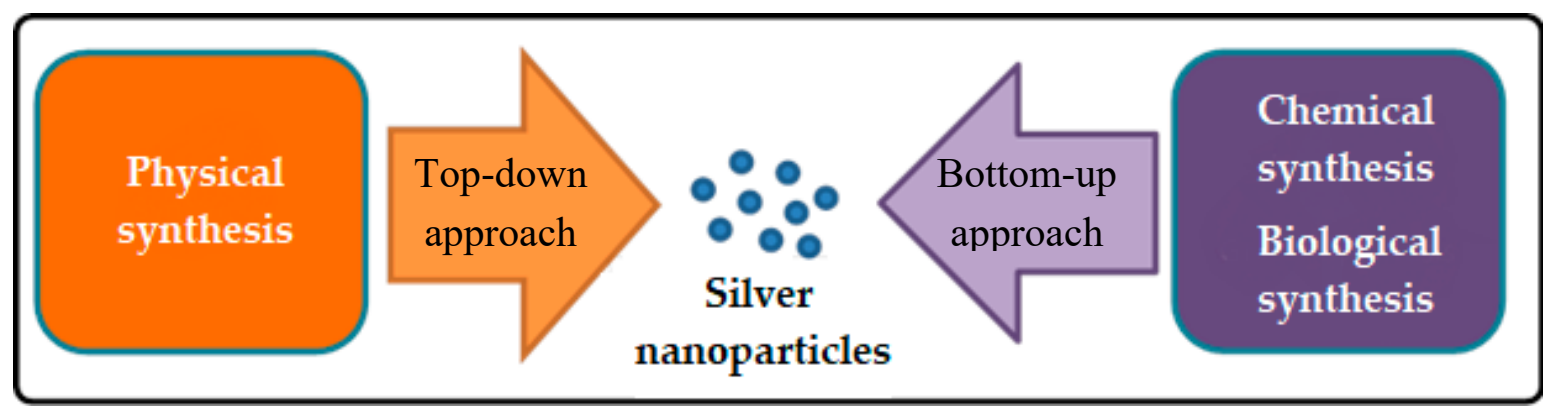

Figure 1. Method of preparing silver nanoparticles.

\subsection{Physical Synthesis of AgNPs}

Physical synthesis of AgNPs excels in producing a uniform and fair distribution of AgNPs prepared on a thin film due to the absence of solvent contamination. Vapor condensation method and laser ablation are the widely used physical approaches in the synthesis of AgNPs [21]. Vapor condensation method is a two-step method involving the process of evaporation and condensation which carry out in a tube furnace at atmospheric pressure [22]. The range of nanoparticles' size obtained from this method are in the range of $3 \mathrm{~nm}$ to $50 \mathrm{~nm}$. The drawbacks of physical synthesis of AgNPs are it is a time-consuming process and require a high amount of energy which can also cause the environmental temperature to rise. It is also difficult to achieve thermal stability due to high energy requirement e.g., a typical tube furnace requires high power consumption more than several kilowatts and preheating time of several minutes in order to reach a stable operating temperature [23]. Therefore, 
there have been numerous alternatives to physical methods instead of implementing the evaporation and condensation method.

Another example of the physical synthesis of AgNPs is done by the laser ablation method that results in the average size of AgNPs between $10 \mathrm{~nm}$ to $30 \mathrm{~nm}$. In brief, the process includes laser ablation of bulk metallic silver salts or materials in solution phase [24]. Pure colloidal AgNPs can be produced due to the absence of chemical reagents in the solvents. However, this method is dependent on the laser wavelength, fluency, ablation duration, liquid medium (with or without surfactants), and the duration of laser pulses in femto-, pico-, and nano-second regime). Zhang and his fellow researcher have stated that there is more frequent usage of Femtosecond Laser Ablation in Liquids (fs LAL) due to its efficiency in controlling the particle size and material ablation [25]. Silver nanoparticles that have 13 to $18 \mathrm{~nm}$ particle size were prepared through fs LAL at $400 \mathrm{~nm}$.

\subsection{Chemical Synthesis of AgNPs}

Chemical synthesis has been widely used as an alternative method in preparing silver nanoparticles in colloidal dispersion. The chemical method of preparing AgNPs involves water or organic solvents in order to reduce the silver metal salts. This process involves three components which are reducing agents, metal precursors, and stabilizing or capping agents. Reducing and capping agents is an important step in producing AgNPs because it can alter the characteristics of AgNPs according to its applications and purposes e.g., AgNPs in dental applications required particles size of $15-20 \mathrm{~nm}$. The selection of reducing agents is a rate-limiting process used to achieve the specific characteristics of AgNPs in terms of size, physicochemical properties as well as prevent the coagulation of AgNPs [26]. The disadvantage of preparing AgNPs using chemical synthesis is that the materials used are toxic and hazardous [27]. The nanoparticles also exposed to surface contamination due to chemical sedimentation and the uses of chemical reducing agents are harmful. However, chemical synthesis is able to provide higher yields, easy to reproduce AgNPs, and it has lower cost in comparison with the physical methods.

The productions of silver nanoparticles with different morphologies and sizes have already been reported in various articles. Table 2 shows the simplified version of the chemical synthesis of AgNP. Wang et al. 2004 have conducted an experiment to reduce silver nitrate into nanoparticles in the presence of polyvinyl pyrrolidone (PVP) which result in the formation of AgNPs with a size range of 20 to $70 \mathrm{~nm}$ [28]. The experiment uses glucose as reducer and sodium hydroxide as an accelerator of the chemical reaction. There are two possible ways of silver reduction in an aqueous PVP solution. The first equation involves the reaction of the silver ion with PVP generating complex ion (Equation (1)). Then, the hydroxyl ion undergoes nucleophilic addition reaction with glucose then reduces silver ion (Equation (2)). Meanwhile, the third equation involves the reaction of silver ions with hydroxyl ion producing $\mathrm{Ag}_{2} \mathrm{O}$ (Equation (3)) which then reduced by glucose causing generation of silver particles (Equation (4)). The reaction between glucose and silver ion in PVP solution can be written as follows:

$$
\mathrm{Ag}^{+}+\mathrm{PVP} \rightarrow \mathrm{Ag}(\mathrm{PVP})^{+}
$$

$$
\begin{aligned}
\mathrm{CH}_{2} \mathrm{OH}(\mathrm{CHOH})_{4} \mathrm{CHO}+2[\mathrm{Ag}(\mathrm{PVP})]^{+}+2 \mathrm{OH}^{-} & \rightarrow \mathrm{CH}_{2} \mathrm{OH}(\mathrm{CHOH})_{4} \mathrm{COOH}+2 \mathrm{Ag}(\mathrm{PVP})+\mathrm{H}_{2} \mathrm{O} \\
2 \mathrm{Ag}^{+}+2 \mathrm{OH}^{-} & \rightarrow \mathrm{Ag}_{2} \mathrm{O}+\mathrm{H}_{2} \mathrm{O} \\
\mathrm{Ag}_{2} \mathrm{O}+\mathrm{CH}_{2} \mathrm{OH}(\mathrm{CHOH})_{4} \mathrm{CHO}+2 \mathrm{PVP} & \rightarrow \mathrm{CH}_{2} \mathrm{OH}(\mathrm{CHOH})_{4} \mathrm{COOH}+2 \mathrm{Ag}(\mathrm{PVP})
\end{aligned}
$$


Table 2. The chemical synthesis of AgNP.

\begin{tabular}{|c|c|c|}
\hline Reaction & Results & References \\
\hline $\begin{array}{c}\text { Turkevich method: Reduction of silver nitrate with } \\
\text { sodium citrate }\end{array}$ & $\begin{array}{l}\text { The particles size of } 14 \mathrm{~nm} \text { with a } \\
\text { mean diameter of } 10 \mathrm{~nm}\end{array}$ & [29] \\
\hline $\begin{array}{l}\text { Reduction of silver nitrate with a mixture of } \\
\text { hydrazine hydrate and sodium citrate as reductants; } \\
\text { sodium dodecyl sulfate as a stabilizer }\end{array}$ & $\begin{array}{l}\text { Colloidal solution with the particles } \\
\text { size range of } 8 \text { to } 50 \mathrm{~nm} \text { with a mean } \\
\text { diameter of } 24 \mathrm{~nm}\end{array}$ & [30] \\
\hline $\begin{array}{l}\text { Reduction of silver nitrate with a mixture of two } \\
\text { different reducing agents which are tannic acid and } \\
\text { sodium nitrate }\end{array}$ & $\begin{array}{l}\text { Combination of reducing agents able } \\
\text { to produce monodisperse spherical } \\
\text { silver nanoparticles in } 5 \text { to } 140 \mathrm{~nm}\end{array}$ & [31] \\
\hline $\begin{array}{l}\text { Reduction of silver nitrate by sodium borohydride in } \\
\text { presences of sodium dodecyl sulfate as a stabilizer } \\
\mathrm{Ag}^{+}+\mathrm{BH}_{4}^{-}+3 \mathrm{H}_{2} \mathrm{O} \rightarrow \mathrm{Ag}^{\mathrm{O}}+\mathrm{B}(\mathrm{OH})_{3}+3.5 \mathrm{H}_{2}\end{array}$ & $\begin{array}{l}\text { Formation of colloidal silver } \\
\text { nanoparticles with particles diameter } \\
\text { in a range from } 30 \text { to } 40 \mathrm{~nm}\end{array}$ & [32] \\
\hline $\begin{array}{l}\text { Reduction of silver nitrate with dextrose as reducing } \\
\text { agent in presence of } \mathrm{Na}^{+} \text {-carrying poly }[\gamma \text {-glutamic } \\
\qquad \begin{array}{c}\text { acid] }(\mathrm{PGA}) \\
2 \mathrm{Ag}^{+}+2 \mathrm{OH}^{-} \rightarrow \mathrm{Ag}_{2} \mathrm{O}+\mathrm{H}_{2} \mathrm{O}\end{array} \\
\qquad \mathrm{Ag}_{2} \mathrm{O}+4 \mathrm{NH}_{3}+\mathrm{H}_{2} \mathrm{O} \rightarrow 2\left[\mathrm{Ag}\left(\mathrm{NH}_{3}\right)_{2}\right]^{+}+2 \mathrm{OH}\end{array}$ & $\begin{array}{l}\text { Formation of silver nanoparticles with } \\
\text { an average size of } 37.3 \pm 5.5 \mathrm{~nm} \text { for } 0.5 \\
w \mathrm{t} \% \text { PGA-AgNP and } 17.3 \pm 3.4 \mathrm{~nm} \text { for } \\
2 \mathrm{wt} \% \text { of PGA-AgNP }\end{array}$ & [33] \\
\hline $\begin{array}{l}\text { Reduction of silver nitrate with aniline in the } \\
\text { presence of cetyltrimethylammonium } \\
\text { bromide }(\mathrm{CTAB}) \\
\mathrm{Ph}-\mathrm{NH}_{2}+\mathrm{Ag}^{+} \rightarrow \mathrm{Ph}-\mathrm{NH}_{2}-\mathrm{Ag}^{+} \\
\mathrm{Ph}-\mathrm{NH}_{2}-\mathrm{Ag}^{+} \rightarrow \text { Anilino radical }+\mathrm{Ag}^{\mathrm{O}}+\mathrm{H}_{2} \mathrm{O}\end{array}$ & $\begin{array}{l}\text { Formation of spherical nanoparticles } \\
\text { in size range from } 10 \text { to } 30 \mathrm{~nm} \text { and } \\
\text { wide size distribution }\end{array}$ & [34] \\
\hline $\begin{array}{c}\text { Reduction of silver nitrate with trisodium citrate } \\
4 \mathrm{Ag}^{+}+\mathrm{C}_{6} \mathrm{H}_{5} \mathrm{O}_{7} \mathrm{Na}_{3}+2 \mathrm{H}_{2} \mathrm{O} \rightarrow 4 \mathrm{Ag}^{\mathrm{O}}+\mathrm{C}_{6} \mathrm{H}_{5} \mathrm{O}_{7} \mathrm{H}_{3}+ \\
\qquad 3 \mathrm{Na}^{+}+\mathrm{H}^{+}+\mathrm{O}_{2} \uparrow\end{array}$ & $\begin{array}{l}\text { Formation of silver nanoparticle with } \\
\text { particle size range from } 5 \text { to } 100 \mathrm{~nm}\end{array}$ & [35] \\
\hline $\begin{array}{l}\text { Reduction of silver nitrate with two different } \\
\text { reducing agents which are ethylene glycol (EG) and } \\
\text { glucose in the presence of poly[N-vinylpyrolidone] } \\
(\mathrm{PVP}) \text { as a stabilizer } \\
2 \mathrm{AgNO}_{3}+\mathrm{R}-\mathrm{CHO}+2 \mathrm{NaOH} \rightarrow 2 \mathrm{Ag}+\mathrm{R}-\mathrm{COOH}+ \\
2 \mathrm{NaNO}_{3}+\mathrm{H}_{2} \mathrm{O}\end{array}$ & $\begin{array}{l}\text { Spherical silver nanoparticles with } \\
\text { particle size range from } 10 \text { to } 250 \mathrm{~nm}\end{array}$ & [36] \\
\hline
\end{tabular}

\subsection{Biological Synthesis of AgNPs}

To overcome the disadvantages of the chemical synthesis of AgNPs, biological methods have been preferred and are thus well studied as an alternative method in preparing silver nanoparticles. The application of biologically-mediated synthesis is proven to be cost-effective, simple, and environmentally friendly as it does not use hazardous or toxic chemicals [37]. This approach has been given much attention as it produces the high yield of AgNPs and it replaces chemicals with bacteria, plant extracts, and small biomolecules such as amino acids. The green synthesis involves three important factors: (1) solvent, (2) reducing agents, and (3) non-toxic material [38]. The advantages of this method are the availability of biological resources used as reducing agents, the high stability in a short production time and the readily soluble nanoparticles.

A previous study had extensively discussed the differences between chemical and biological methods of producing AgNPs [39]. The chemical synthesis was performed by the following method suggested by Fang, Zhang, and Mu using sodium citrate as the reducing agent while the biological synthesis was done by using white-rot fungi Pycnoporus sp. [40]. The study concluded that the synthesis of AgNPs by chemical reduction is dependent on the reducing agents and stabilizer which controls the particles aggregation and other parameters while green synthesis dependent on the enzymes secreted by the fungi. The production of AgNPs by fungi occurs in these two steps: (1) entrapment of the silver ions at the surface of the fungi and (2) the reduction of AgNPs by the enzyme secreted from fungal system [41]. Table 3 shows the simplified information on the biological synthesis of AgNPs. 
These synthesized nanoparticles also show positive antibacterial properties where its mechanism of action will be explained in this review.

Table 3. The green synthesis of silver nanoparticles (AgNPs).

\begin{tabular}{|c|c|c|}
\hline Substances & Results & Reference \\
\hline \multicolumn{3}{|c|}{ (a) Plants } \\
\hline Artemisia nilagirica extract & $\begin{array}{l}\text { The size diameters of the nanoparticles are in the range of } 70 \text { to } \\
90 \mathrm{~nm} \text { and the size distribution in the range of } 2 \text { to } 4 \mathrm{keV} \text {. There } \\
\text { was no impurity found. }\end{array}$ & {$[42]$} \\
\hline $\begin{array}{l}\text { Leaves extract of Catharanthus roseus. Linn. } \\
\text { G. Donn }\end{array}$ & $\begin{array}{l}\text { The size of nanoparticles is } 27 \pm 2 \mathrm{~nm} \text { with zeta-potential of } \\
-63.1 \mathrm{mV} \text { which indicate good dispersity and stability. }\end{array}$ & {$[43]$} \\
\hline Boerhaavia diffusa plant extract & $\begin{array}{l}\text { The average particles size is } 25 \mathrm{~nm} \text { with cubic morphology of } \\
\text { silver nanoparticles. }\end{array}$ & {$[44]$} \\
\hline Ethanolic extract of Terminalia fagifolia Mart. & $\begin{array}{l}\text { Formation of spherical or polygonal silver nanoparticles with a } \\
\text { size range of } 66 \text { to } 81 \mathrm{~nm} \text { with high polydispersity. }\end{array}$ & {$[45]$} \\
\hline Rosemary leaf aqueous extract & $\begin{array}{l}\text { The silver nanoparticles are in a spherical shape with a diameter } \\
\text { size of } 14 \mathrm{~nm} \text { with high purity. }\end{array}$ & {$[46]$} \\
\hline Butea monosperma (BM) leaf extract & $\begin{array}{l}\text { Formation of triangular and spherical nanoparticles with a size } \\
\text { range of } 20 \text { to } 80 \mathrm{~nm} .\end{array}$ & {$[15]$} \\
\hline $\begin{array}{l}\text { Curcumin:hydroxypropyl- } \beta \text {-cyclodextrin } \\
\text { (CUR:HP } \beta C D)\end{array}$ & $\begin{array}{c}\text { Formation of spherical silver nanoparticles with an average size } \\
\text { of } 42.71 \pm 17.97 \mathrm{~nm} \text { and homogeneous dispersion } \\
\text { of nanoparticles. }\end{array}$ & {$[47]$} \\
\hline \multicolumn{3}{|c|}{ (b) Fungus } \\
\hline Biosorption by Aspergillus flavus & $\begin{array}{l}\text { Production of monodisperse silver nanoparticles with an } \\
\text { average particle size of } 8.92 \pm 1.61 \mathrm{~nm} \text { and size distribution } \\
\text { about } 1000 \text { nanoparticles. }\end{array}$ & {$[48]$} \\
\hline Cladosporium cladosporioides & $\begin{array}{l}\text { Formation of high-density silver nanoparticles with average size } \\
\text { of } 24 \mathrm{~nm} \text { with uniform dispersion. }\end{array}$ & {$[49]$} \\
\hline Guignardia sp. & $\begin{array}{l}\text { The size of silver nanoparticles in the range of } 5 \mathrm{~nm} \text { and } 20 \mathrm{~nm} \\
\text { with fairly monodisperse nature. }\end{array}$ & {$[50]$} \\
\hline \multicolumn{3}{|c|}{ (c) Bacteria } \\
\hline Bacillus sp. & $\begin{array}{l}\text { Development of silver nanoparticles with a size range of } 5 \text { to } \\
15 \mathrm{~nm} \text { observed in the periplasmic space of bacterial cells. }\end{array}$ & {$[51]$} \\
\hline Bacillus subtilis & The average size of silver nanoparticles produces is $6.1 \pm 1.6 \mathrm{~nm}$. & [52] \\
\hline Escherichia coli & $\begin{array}{l}\text { The process yielded an average size particle of } 50 \mathrm{~nm} \text { with a } \\
\text { uniform distribution at } 50 \mathrm{~nm} .\end{array}$ & {$[53]$} \\
\hline
\end{tabular}

\section{Mechanism of Action}

Silver has become one of the most widely studied oligodynamic materials due to its range of bactericidal activities, effectiveness, low toxicity, and various application as disinfectant. The oligodynamic effect is the biocidal effects of metals, especially heavy metals, which could occur in low concentrations of heavy metals. Silver nanoparticles (AgNPs) have proven to have oligodynamic effect due to their large surface areas with its ability to bind with bacterial biomolecules, the ability to penetrate the cells, generation of reactive oxygen species (ROS) and free radicals, and act as modulators in signal transduction pathways of microorganisms [54]. The broad-spectrum of oligodynamic materials, in particularly AgNPs, could enhanced the development of nanotherapeutics such as antibiotics have received a lot of attention.

The surface modification of AgNPs can also affect the oligodynamics effect of nanoparticles as surface modification can stabilize these nanoparticles e.g., modification of AgNPs with polyimide. There is a study that has proven half encapsulation of AgNPs with loosely polyimide can increase the antibacterial activity of these nanoparticles as well as improve the silver stability [55]. Coating with polydopamine and hydrofluoric acid etched glass spheres (PDA-HF/GSs) have shown strong adhesion towards E. coli and Bacillus [56]. Thus, preventing the formation of biofilm. Modification of AgNPs 
by incorporating metal oxide through a solution casting method exhibited a uniform dispersion of nanoparticles. These modified nanoparticles also inhibit the growth of Escherichia coli and Staphylococcus aureus as well as prevent formation of film [57].

The antibacterial effects of AgNPs are more complex compare with other metallic nanoparticles and shows lower toxicity toward cells. Some metallic nanoparticles show higher antibacterial activity than AgNPs but are toxic towards cell, e.g., copper nanoparticles (CuNPs). CuNPs show greater ability to inhibit bacterial growth than AgNPs as their mechanism of action involve rupture of bacterial membrane and electron transfer by photocatalytic process [58]. Even though CuNPs have higher antimicrobial activity, they are more instable and have higher possibility to convert into CuONPs through oxidation process. Meanwhile, gold nanoparticles (AuNPs) have lower ability to inhibit bacterial growth in comparison with AgNPs as they do not exhibit apparent intrinsic antibacterial activity. Their mechanism of action only involve adhesion on the bacterial surface through electrostatic forces [59]. This mechanism of action is dependent on the size of nanoparticles, the smaller the nanoparticles, the smaller minimum inhibition concentration (MIC) [60]. On the other hand, antiviral properties of other metallic nanoparticles work the same mechanism as AgNPs. The antiviral activity of metallic nanoparticles consists of competitive binding with cell receptor and rupture of viral envelope [61]. Therefore, the antibacterial and antiviral properties of AgNPs are further discussed below.

\subsection{Antibacterial Properties of AgNPs}

Silver nanoparticles (AgNPs) have caught the attention of researchers due to its broad spectrum of antifungal and antibacterial properties. New developments of antibacterial products or agents are in dire need due to resistance of microbial towards antibiotics through mutation. Moreover, the low reactivity of AgNPs compared to the silver ions made them suitable for clinical and therapeutic application [62]. There are four known antimicrobial actions of AgNPs: (1) adhesion towards the surface membrane of microbial. (2) Penetration of AgNPs into the cells and cause disruption of biomolecules and intracellular damage, (3) induce cellular toxicity by generating ROS which trigger the oxidative stress of cell, and (4) disrupt the signal transduction pathways of the cells [63]. Figure 2 shows the overall mechanism of action in bacteria.

When the microbes are exposed to AgNPs, the nanoparticles tend to stick or adhere to the cell wall or membrane of microbes due to the electrostatic attraction between the positive charge of silver ions which is generated from oxidation of AgNPs and the negatively charged cell membrane of microorganisms [64]. AgNPs also have strong affinity towards the sulfur-containing proteins in the microbial cell wall. The attachment of AgNPs towards the membrane of microbes causes irreversible morphological changes in the structure of cell membrane [65]. This can also cause a loss in the integrity of lipid bilayer and the permeability of the cell membrane. Alteration in cell structure can cause increased permeability of the cell membrane which in turn affects the cell ability to regularly regulate activity. For instance, the release of the silver ions by the nanoparticles will alter transport and releases of potassium ions $(\mathrm{K}+)$, thus affecting the transport activity of cells. Increase in cell membrane permeability may also cause loss or leakage of cellular contents such as cytoplasm, proteins, ions, and cellular energy reservoir, ATP, which can induce the ghost cell effect of the microorganisms. The ghost cell effect in bacteria occurs when the expulsion of the cell or microbial contents leaving a hollow envelope of the microorganisms [66]. Transmission electron microscopic (TEM) images have illustrated that AgNPs affect the integrity of Gram-negative bacteria (E. coli and S. typhimurium) membrane by depolarization and destabilization of membrane [67]. 


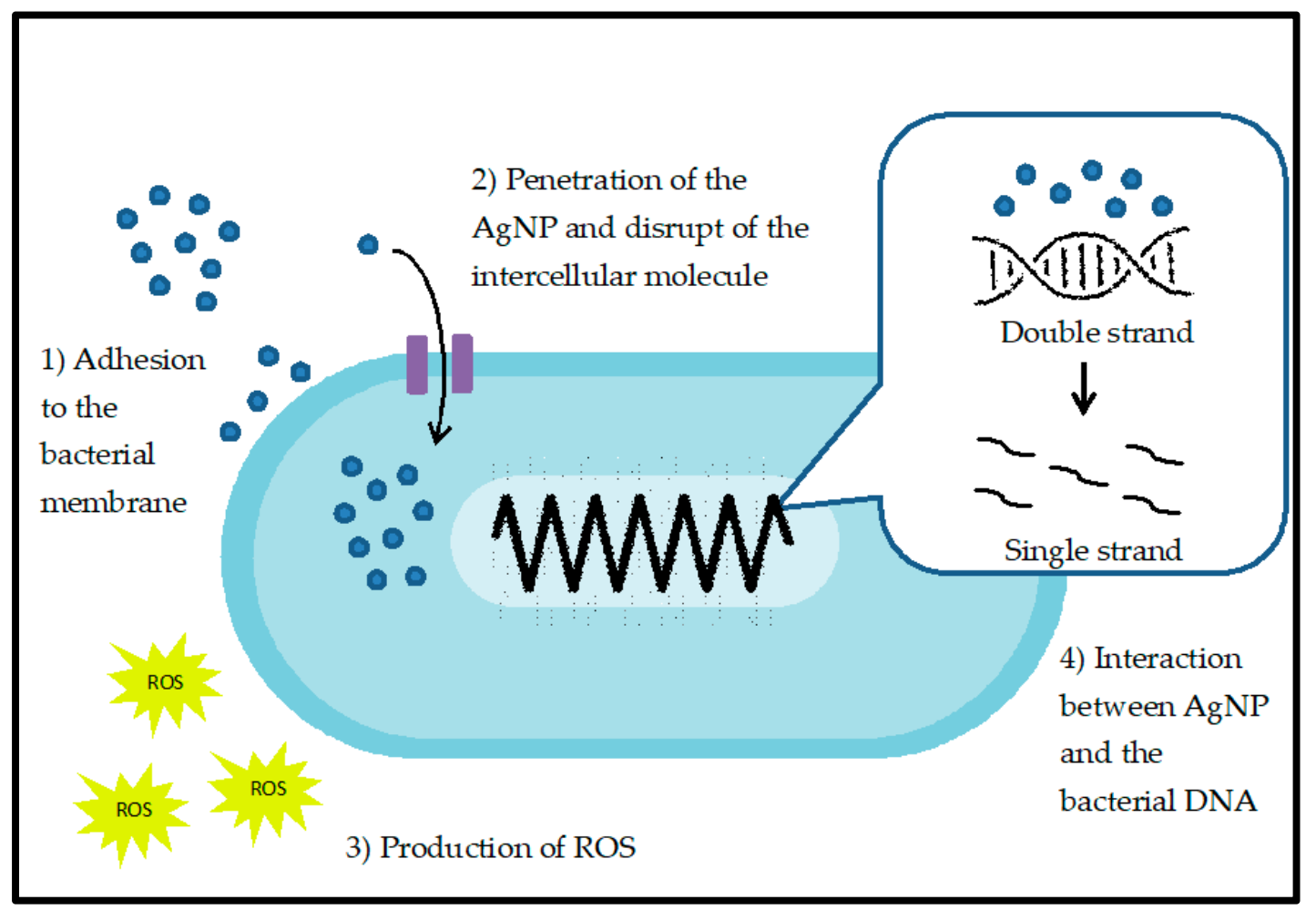

Figure 2. Antibacterial activities of silver nanoparticles.

As the AgNPs bind to the surface of the microbial membrane, they can also penetrate the cells and affect important biomolecules and cellular activity. AgNPs can enter the bacterial cells through a water-filled channel called porins in the outer membrane of Gram-negative bacteria such as E. coli. After penetration of AgNPs into the cells, these nanoparticles will start to bind with cellular structures and biomolecules such as proteins, lipids, and DNA, thus damaging the internal structure of the bacteria. The silver ions that have been released into the environment will bind to negatively charge protein which altering the protein structurally and eventually result in deactivation the proteins. The result from Li et al. (2010) proved that the AgNP inhibits the respiratory chain dehydrogenase by conversion of various enzymes such as glycerol-3-phosphate dehydrogenase into dihydroxyacetone in S. aureus (Gram-positive bacteria), and thus interfere with normal growth and metabolism of the bacteria cells [68]. Additionally, AgNPs can interact with bacterial DNA causing denaturation of DNA and interrupt the cell growth of the microbes [69]. AgNPs can decrease the stability of DNA structure by electrostatic repulsion due to the DNA and AgNPs having the same polar charge [70]. Sadoon et al. (2020) have shown that silver ions can interact with DNA thus causing hybridization of doubles-stranded DNA which involves dissociation of double strands into single strands by disrupting the H-bonds of DNA strands [71].

Another mechanism of action in AgNPs is the production of reactive oxygen species (ROS) which normally causes cellular oxidative stress in microbes. ROS is a general term for oxygenated compounds that involved in various cellular biological events such as superoxide, hydrogen peroxide and hydroxyl radicals. The antibacterial potential of AgNPs is usually related to the ability of nanoparticles to produce ROS and free radicals and eventually increase the oxidative stress in cells. Productions of intercellular ROS have become the most important indicator towards toxicity related to nanoparticles as they may induce lipid damage, leakage of cellular biomolecules and eventually lead to cell apoptosis [72]. Song et al. (2018) have found out that treatment with curcumin and AgNPs may enhance the antibacterial properties towards B. sublitis and E. coli by increasing the formation of ROS which leads to membrane damage and is followed by cell death [73]. The TEM results of the study described that the rupture of the cell membrane in the treated group with curcumin and AgNPs. 
Zhang et al. (2019) suggested that the production of ROS is primarily dependent on the concentration or dose of AgNPs [74]. The study has shown that the production of ROS was dependent on the size of silver nanoparticles where AgNPs with a concentration of $10 \mathrm{mg} / \mathrm{L}$ cause the highest level of ROS generation in $A$. vinelandii and $N$. europaea which were treated with $10 \mathrm{mg} / \mathrm{L}$ and $50 \mathrm{mg} / \mathrm{L}$ of $\mathrm{AgNP}$.

The mechanism of signaling pathway depends on the phosphorylation and dephosphorylation cascade of protein or enzymes which are essential for cellular activity and bacterial growth. Due to unique physicochemical properties of AgNPs, there is a possibility for these nanoparticles to act as modulators of signal transduction in microbial cells [75]. Jena et al. (2020) had demonstrated that the gold-silver nanoparticles able to mediate apoptosis of bacteria cell by disrupting the bacterial actin cytoskeletal network [76]. The result shows that the nanoparticles affect the actin cytoskeleton MreB causing morphological changes in the bacterial shape thus increase the fluidity in the membrane which follow by rupture of cells. MreB, an actin homologue, plays an important role in regulating the localization of cell shapes and cell survival. Table 4 shows the antibacterial studies of AgNPs and their mechanism of action. As these nanoparticles show effective oligodynamic effects on bacteria, there also some studies that shown their effects towards viruses.

Table 4. The antibacterial properties of AgNPs.

\begin{tabular}{|c|c|c|c|c|}
\hline Bacteria & $\begin{array}{l}\text { Type of } \\
\text { Bacteria }\end{array}$ & $\begin{array}{l}\text { Silver Nanoparticles } \\
\text { Size }\end{array}$ & Mechanism of Action & References \\
\hline $\begin{array}{l}\text { Pseudomonas } \\
\text { aeruginosa }\end{array}$ & Gram-negative & $\begin{array}{l}\text { Average particles size } \\
\text { of } 45 \mathrm{~nm}\end{array}$ & $\begin{array}{l}\text { Interaction with ROS and attachment of } \\
\text { AgNPs at microbial cell wall }\end{array}$ & [77] \\
\hline $\begin{array}{l}\text { Escherichia coli } \\
\text { AB1157 }\end{array}$ & Gram-negative & $\begin{array}{c}\text { Average mean } \\
\text { diameter } 8.3 \pm 1.9 \mathrm{~nm}\end{array}$ & $\begin{array}{l}\text { Damage the cellular DNA by influencing the } \\
\text { base excision repair system }\end{array}$ & [78] \\
\hline $\begin{array}{c}\text { Staphylococcus aureus } \\
\text { ATCC25923 }\end{array}$ & Gram-positive & \multirow{2}{*}{$\begin{array}{c}\text { Average size of } \\
3.91 \mathrm{~nm}, 2.29 \mathrm{~nm} \text {, and } \\
1.59 \mathrm{~nm}\end{array}$} & \multirow{2}{*}{$\begin{array}{l}\text { Destruction of microbial cell membrane and } \\
\text { rise of ROS concentration }\end{array}$} & \multirow{2}{*}{ [79] } \\
\hline $\begin{array}{l}\text { Escherichia coli } \\
\text { ATCC25922 }\end{array}$ & Gram-negative & & & \\
\hline Escherichia coli DH5 $\alpha$ & Gram-negative & \multirow[b]{2}{*}{ Average size of $30 \mathrm{~nm}$} & \multirow[b]{2}{*}{$\begin{array}{l}\text { Accumulation of AgNPs in the cell wall and } \\
\text { cell membrane of bacterial cell }\end{array}$} & \multirow[b]{2}{*}[80]{} \\
\hline $\begin{array}{c}\text { Bacillus } \\
\text { Calmette-Guérin }\end{array}$ & $\begin{array}{l}\text { Acid-fast } \\
\text { Gram-positive }\end{array}$ & & & \\
\hline $\begin{array}{l}\text { Multidrug resistant } \\
\text { Escherichia coli (MC-2) }\end{array}$ & Gram-negative & \multirow[b]{2}{*}{$\begin{array}{l}\text { Average size of } \\
18 \pm 3 \mathrm{~nm}\end{array}$} & \multirow[b]{2}{*}{$\begin{array}{l}\text { Disruption of cell membrane through } \\
\text { formation of ROS }\end{array}$} & \multirow[b]{2}{*}{ [81] } \\
\hline $\begin{array}{l}\text { Multidrug resistant } \\
\text { Staphylococcus aureus } \\
\text { (MMC-20) }\end{array}$ & Gram-positive & & & \\
\hline Proteus sp. & Gram-negative & \multirow{2}{*}{ Average size of $38 \mathrm{~nm}$} & \multirow{2}{*}{$\begin{array}{l}\text { Cell wall ruptured and inhibit DNA } \\
\text { replication thus inhibit the bacterial growth }\end{array}$} & \multirow{2}{*}{ [82] } \\
\hline Klebsiella sp. & Gram-negative & & & \\
\hline Staphylococcus aureus & Gram-positive & \multirow{5}{*}{$\begin{array}{l}\text { Size of nanoparticles } \\
\text { should be lower than } \\
100 \mathrm{~nm} \text {. The articles } \\
\text { do not mention the } \\
\text { size of AgNPs }\end{array}$} & \multirow{5}{*}{$\begin{array}{c}\text { Oxidative stress which cause alteration in } \\
\text { kynurenine protein. Activation of } \\
\text { kynurenine pathways thus inhibit the } \\
\text { bacterial growth }\end{array}$} & \multirow{5}{*}{ [83] } \\
\hline Escherichia coli & Gram-negative & & & \\
\hline $\begin{array}{l}\text { Pseudomonas } \\
\text { aeruginosa }\end{array}$ & Gram-negative & & & \\
\hline Bacillus subtilis & Gram-positive & & & \\
\hline Klebsiella pneumoniae & Gram-negative & & & \\
\hline
\end{tabular}

\subsection{Antiviral Properties of AgNPs}

The recent outbreaks of an infectious disease caused by a newly evolving pathogenic virus, which has developed resistance towards available antiviral drugs, has encouraged numerous researchers in the search for new antiviral agents. The viral disease depends on the entry and attachment of the virus onto the host cells by binding of viral surface components with ligands and proteins on the cell membrane. The best strategy in developing new antiviral agents is to interfere with the interactions of virus ligand and cell membrane, thereby blocking the attachment and entry of the virus into the cells. By considering the metal nanoparticles mechanism of action in microbes, silver nanoparticles (AgNPs) have become one of the strongest candidates as antiviral agents. The broad attack ranges of AgNPs towards its target have made resistance of microbes towards these nanoparticles become futile. 
Figure 3 shows a diagram that generally explains the AgNP mechanism of action towards a virus. There are a few types of research on the effects of AgNPs towards viruses. However, the details of the interaction are limited. The complexity of virus structures can contribute to the limited knowledge of nanoparticles mechanism towards the viruses. There are two ways the AgNP interacts with the pathogenic virus: (1) the AgNP will bind to the outer coat of the virus thus inhibit the attachment of virus towards cell receptors and (2) the AgNP will bind to the DNA or the RNA of the virus thus inhibiting the replication or propagation of the virus inside the host cells. Table 5 show the antiviral properties of AgNPs towards different types of pathogenic virus. Understanding these nanoparticle's mechanism of action towards different types of viruses could develop new viral therapy by using nanotechnologies.

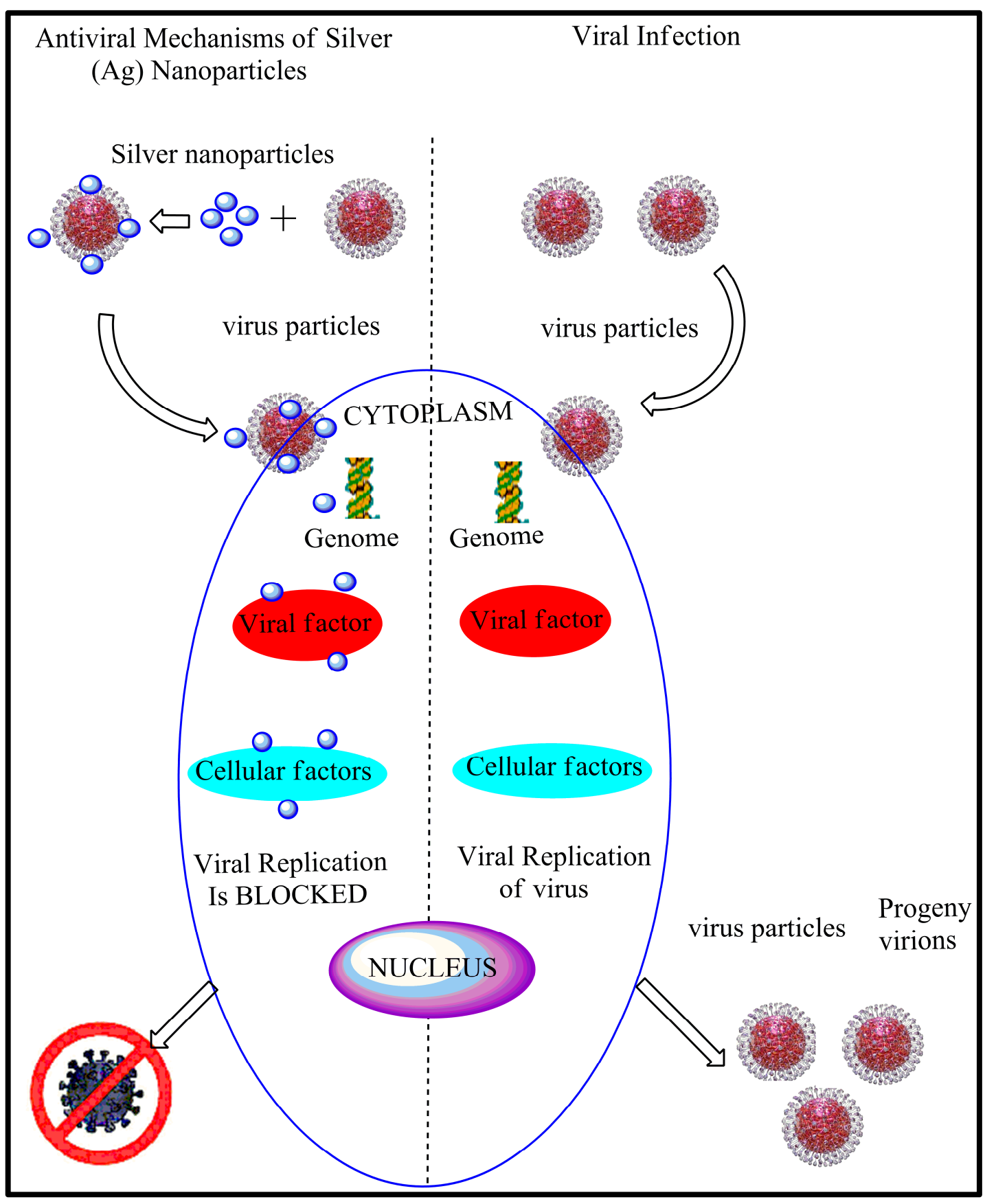

Figure 3. The antiviral activities of silver nanoparticles. 
Table 5. The antiviral properties of AgNPs.

\begin{tabular}{|c|c|c|c|c|}
\hline Virus & Family & $\begin{array}{l}\text { Silver Nanoparticles } \\
\text { Composition }\end{array}$ & Mechanism of Action & References \\
\hline $\begin{array}{l}\text { Herpes simplex virus } \\
\text { type } 2 \text { (HSV-2) }\end{array}$ & Herpesviridae & $\begin{array}{l}\text { Tannic acid-modified silver } \\
\text { nanoparticles }(13 \mathrm{~nm})\end{array}$ & $\begin{array}{l}\text { Interact with viral } \\
\text { glycoproteins thus interfere } \\
\text { with cell attachment }\end{array}$ & [84] \\
\hline Bacteriophage MS2 & Leviviridae & \multirow{2}{*}{$\begin{array}{l}\text { Magnetic hybrid colloid silver } \\
\text { nanoparticles }(15 \mathrm{~nm})\end{array}$} & \multirow{2}{*}{$\begin{array}{l}\text { Damage proteins of the } \\
\text { viral coat }\end{array}$} & \multirow{2}{*}{ [85] } \\
\hline Murine novovirus & Caliciviridae & & & \\
\hline $\begin{array}{l}\text { Herpes simplex virus } \\
\text { type } 1 \text { and type } 2 \\
\text { (HSV-1 \& HSV-2) }\end{array}$ & Herpesviridae & \multirow{2}{*}{$\begin{array}{l}\text { Mycosynthsized silver } \\
\text { nanoparticles }(4-31 \mathrm{~nm})\end{array}$} & \multirow{2}{*}{$\begin{array}{l}\text { Block interaction of virus and } \\
\text { cells }\end{array}$} & \multirow[t]{2}{*}{ [86] } \\
\hline $\begin{array}{l}\text { Human parainfluenza } \\
\text { virus type } 3 \text { (hPIV3) }\end{array}$ & Paramyxoviridae & & & \\
\hline $\begin{array}{c}\text { Human } \\
\text { immunodeficiency } \\
\text { virus (HIV) }\end{array}$ & Retroviridae & $\begin{array}{c}\text { PVP-coated silver } \\
\text { nanoparticles }(30-50 \mathrm{~nm})\end{array}$ & $\begin{array}{l}\text { Inhibit the interaction between } \\
\text { gp120 and cell } \\
\text { membrane receptors }\end{array}$ & [87] \\
\hline H1N1 influenza A & Orthomyxoviridae & $\begin{array}{c}\text { Chitosan-coated silver } \\
\text { nanoparticles }(3.5,6.5, \text { and } \\
12.9 \mathrm{~nm})\end{array}$ & $\begin{array}{l}\text { Inhibit the viral contact with } \\
\text { host cells and interaction of } \\
\text { silver nanoparticles with } \\
\text { viral glycoproteins }\end{array}$ & [88] \\
\hline Poliovirus & & $\begin{array}{l}\text { Pure silver nanoparticles } \\
\qquad(7.1 \mathrm{~nm})\end{array}$ & $\begin{array}{l}\text { Bind with the viral particles } \\
\text { thus prevent binding with } \\
\text { host receptor and inhibition of } \\
\text { viral proteins }\end{array}$ & [89] \\
\hline $\begin{array}{l}\text { Respiratory syncytial } \\
\text { virus (RSV) }\end{array}$ & Paramyxoviridae & $\begin{array}{l}\text { PVP-coated silver } \\
\text { nanoparticles }(10 \mathrm{~nm})\end{array}$ & $\begin{array}{l}\text { Interfere with virus } \\
\text { attachment by binding with } \\
\text { gp120 glycoprotein }\end{array}$ & [90] \\
\hline $\begin{array}{l}\text { Hepatitis B virus } \\
\text { (HBV) }\end{array}$ & Hepadnaviridae & $\begin{array}{l}\text { Silver nanoparticles } \\
\quad(10 \text { and } 50 \mathrm{~nm})\end{array}$ & $\begin{array}{l}\text { Reduce the formation of HBV } \\
\text { DNA by binding with the } \\
\text { HBV dsDNA and virions }\end{array}$ & [91] \\
\hline $\begin{array}{l}\text { Adenovirus type } 3 \\
\text { (Ad3) }\end{array}$ & Adenoviridae & Silver nanoparticles $(11.4 \mathrm{~nm})$ & $\begin{array}{l}\text { Damaging the viral particles } \\
\text { and bind to the viral DNA }\end{array}$ & [92] \\
\hline
\end{tabular}

A virus often triggers a cell's apoptosis when it undergoes the viral replication process. The apoptosis of cells causes the host to have severe symptoms and could cause fatality if not treated. Mitochondrial-mediated apoptosis pathway is an example of signaling pathway that could induce cell apoptosis involving depolarization of mitochondrial membrane potential (MMP). This pathway involves 2 different protein which are Bax and Bcl-2. Bax is the pro-apoptotic protein causing permeabilization of mitochondrial membrane which allow proteins in mitochondrial intermembrane space to escape to the cytosol to induce cell apoptosis while Bcl-2 is the anti-apoptotic protein which inhibit Bax mechanism [93]. Lv et al. 2014 have tested different silver nanomaterials consisting of AgNPs, silver colloids, and 2 different kinds of silver nanowires against transmissible gastroenteritis virus (TGEV) [94]. The article had done pre-clinical tests by infecting TGEV to swine testicle (ST) cells and the results shows that TGEV is able to induce mitochondrial-mediated apoptosis pathway by increasing the Bax levels in the cells. The silver nanomaterials used in this article have shown to inhibit the initiation of TGEV infection by binding to the surface protein, $\mathrm{S}$ glycoprotein. The article also suggested that the silver nanomaterials able to alter the structure of surface proteins thus inhibit their recognition and adhesion towards host receptor. The antiviral activities of these nanomaterials could lower the risk of infection or might as well prevent an epidemic viral disease such as COVID-19.

The Coronavirus disease 19 pandemic, commonly known as COVID-19 is caused by severe acute respiratory syndrome coronavirus 2 (SARS-CoV-2). The coronaviruses belong to family Coronaviridae in Nidovirales order. Coronaviridae often associate with infection in the upper part of respiratory system and the gastrointestinal tract of host. The term "corona" represents morphological structure of the protein spikes on the outer surface of the virus which resemble a crown. The size of coronaviruses are in the range of 65 to $125 \mathrm{~nm}$ in diameter which only contain a single-stranded RNA (size range from 26 to $32 \mathrm{kbs}$ in length) as nucleic material [95]. With the recent outbreak of new viral diseases 
such as COVID-19 that has reached over 8 million cases worldwide, the application of AgNPs could be implemented as treatment. There already is an opinion letter on using silver nanoparticles as the antiviral therapy to treat COVID-19 patients with minimum side effects [96]. The hypothesis was the AgNPs will bind to the spike glycoprotein of the virus thus inhibiting the binding of the virus towards the cells and the release of silver ions can decrease the environmental $\mathrm{pH}$ of respiratory epithelium (where the COVID-19 virus usually reside) to become more acidic which is hostile towards the virus. Figure 4 shows the overall hypothesis of AgNPs antiviral activities against SARS-CoV 2. Both antiviral and antibacterial action of AgNP can be used to contribute to various industries, especially health care, where they can be used to combat infection problems worldwide.

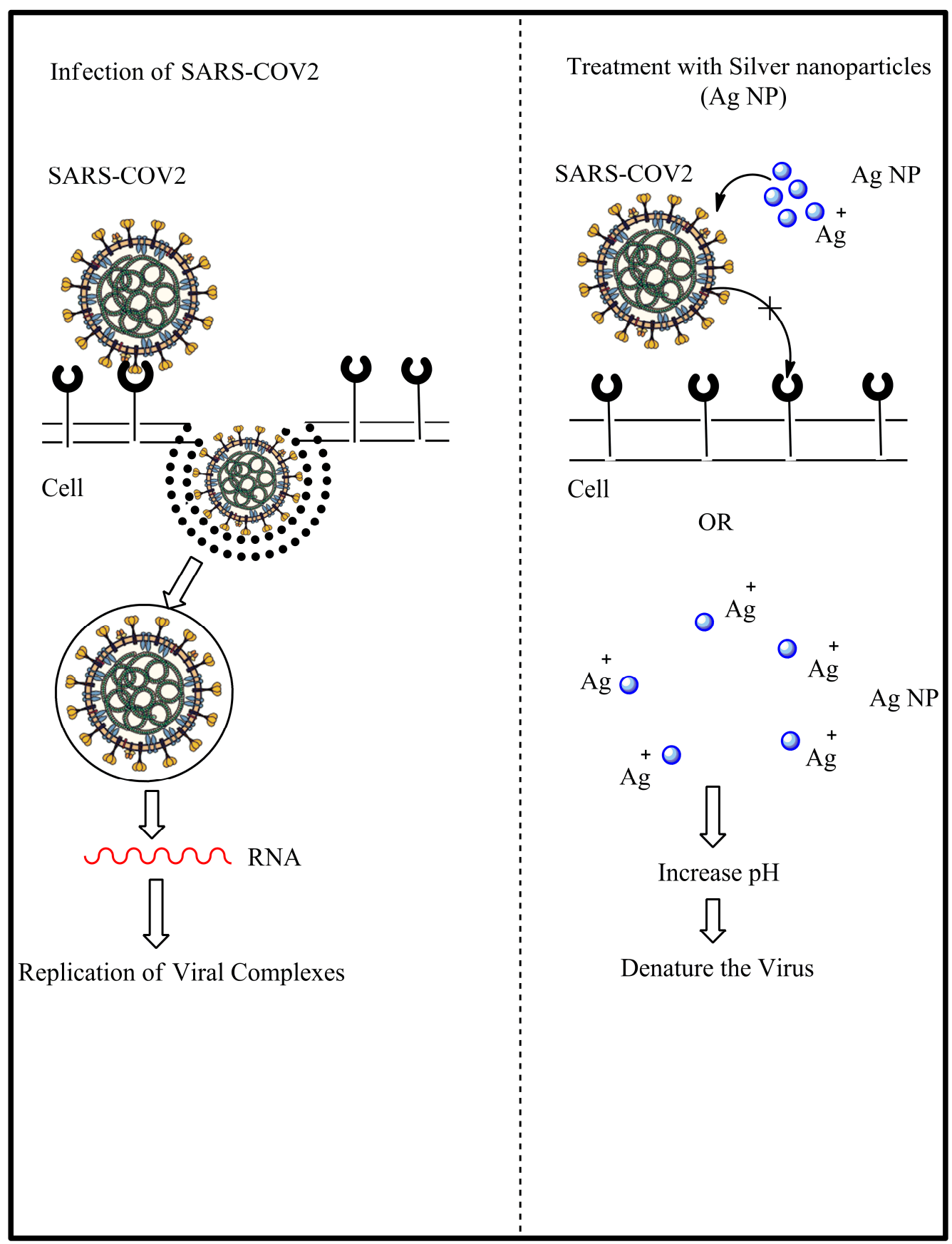

Figure 4. The proposed possible mechanism of action towards severe acute respiratory syndrome coronavirus 2 (SARS-CoV 2). 


\section{Application of AgNPs}

Silver nanoparticles (AgNPs) have been useful in different industrials, e.g., textiles, biomedicines, foods, and electronic applications, due to their unique physicochemical and biological properties. AgNPs are applied as antibacterial agents in disinfectants to water treatment. Moreover, the uses of AgNPs in the textile industry have gained quite a lot of attention due to the greater ion release and increasing catalytic activity as a result of the large surface area per mass of AgNP. The AgNPs are embedded into the fabric by two primary methods: (1) inserting the substrates with pre-formed nanoparticles and (2) inserting the substrates into a solution with silver salts and treating with reducing agents in order to convert silver salts into AgNPs [97]. A silver nanocoated fabric shows a homogeneous distribution of AgNPs and excellent antibacterial activity [98]. Next, the applications of silver in medicine have already been applied for a few decades. AgNPs have been applied as wound dressing products as it has been proven to significantly reduce the wound healing time while simultaneously prevent infection in the wound site [99]. Silver nanoparticles embedded in bacterial cellulose are able to perform the bactericidal activity on a Gram-negative bacterium (E. coli) and non-toxic to epidermal cells [100]. Other than nanoparticles on their own, functionalized AgNPs also have been deemed useful in various industries.

Conjugations of AgNPs with other types of polymers have shown beneficial results especially stabilizing the nanoparticles as well as providing a chemically stable system [101]. Functionalized AgNPs have shown to be useful in the medical industry as it helps in drug delivery or enhancing medical devices. AgNPs that have been functionalized through the process of PEGylation are some of the most commonly used functionalized AgNPs. PEGylation is amalgamation of both covalent and non-covalent of polyethylene glycol (PEG) polymer chain with the nanoparticles, in this case, AgNPs are coated with polyethene glycol (PEG) to improve the drug delivery to targeted cells. PEG coats able to prevent aggregation of nanoparticles as well as increases the circulation time for drug delivery. Hajtuch and fellow researchers have conducted an experiment on functionalized AgNPs with reduced glutathione (GSH), PEG, and lipoic acid (LA) to investigate the effects of AgNPs on human blood platelets [102]. The study has proven that these functionalized AgNPs are able to reduce platelet aggregation which most likely is caused by protein interaction of platelet surface and AgNP.

Functionalization can also increase the antimicrobial activity of these nanoparticles. Addition of platinum can enhance the formation of silver ions through galvanic action thus enhance the efficiency of anti-bacterial activity without affecting cytoxicity [103]. Galvanic action is an electrochemical process where two different metals creating an electron conductive path in the presence of electrolyte, in this case, the electron flow to the AgNP cause increased formation of silver ions. Compounds such as acetic acid can also increase the antimicrobial activity of the nanoparticles [104]. In wound healing application, it is important to control the release of silver ions because excessive formation of silver ions can cause oxidative stress in the cells as the production of reactive oxygen species increases. There are various studies indicating that immobilization of AgNPs has more advantages in comparison with unbounded nanoparticles. $\mathrm{Wu}$ and co-workers have used bacterial cellulose to immobilize AgNPs causing even distribution across the cellulose, stabilization, and minimizing the toxicity of the nanoparticles [100]. While, Balamurugan and co-workers have used a bioglass system incorporated with silver through a process called sol-gel in order to minimize release of silver ions [105]. However, it is beneficial to learn the hazards of AgNP to prevent problems from occurring during application of AgNPs.

\section{Safety of AgNPs}

Silver nanoparticles (AgNPs) have been very useful towards many fields especially the medical field due to their wide range of applications in disinfection. However, there have been a couple of issues regarding AgNPs that are still highly debatable between researchers involving the toxicity and the environmental impact of AgNPs. These nanoparticles are viewed as potential hazards due to its ability to induce cytotoxic mechanisms such as production of reactive oxygen species (ROS), 
DNA damage, and heighten pro-inflammation progress in cells. Due to the unique physicochemical properties of AgNPs, especially production of reactive oxygen (ROS), these nanoparticles can cause sublethal adverse effects when the concentration or production of ROS is not controlled properly [106]. There a study has shown the toxicity of AgNPs by using in vitro model. Mao and co-workers had proven that AgNPs induced high production of ROS causing a defect in formation of larvae which was activated through oxidative stress in Drosophila melanogaster [107]. There was also the case where a patient was diagnosed with argyria due to over-consumption of colloidal silver [108]. Argyria is a rare skin condition which causes cutaneous discoloration due to intake or exposure to silver. Another issue regarding nanoparticles is the effect of AgNPs on the environment. The impacts of AgNPs towards the environment remain unclear due to limitation in current available technologies. However, $\mathrm{Xu}$ and fellow researchers stated that AgNPs have a negative impact on the soil microbiome in the long run [109]. This shows that AgNPs also have limitations.

\section{Limitations of AgNPs}

Silver nanoparticles (AgNPs) are known for their advantages in physicochemical properties in comparison with their bulk structure. However, these nanoparticles have their own limitations whereas one of the limitations is fast reaction with oxygen called oxidation. AgNPs are very sensitive with oxygen as the silver ion will bind to oxygen and form a strong bond called an ionic bond. The formation of this ionic bond will alter the structure of nanoparticles, thus changing the physicochemical properties of nanoparticles. The oxidized AgNPs also reduce the antibacterial properties of AgNPs due to its dependence towards silver ions [110]. Another limitation in AgNPs is the tendency of these particles to be aggregated. There also a study performed by Menazea (2020) that have tested AgNPs in different medium and the result shows that these nanoparticles tend to aggregate in dimethylformamide and tetrahydrofurane solutions which are an organic medium [111].

\section{Conclusions}

The occurrence of nanoparticles, particularly metallic nanoparticles, have been deemed very useful in numerous fields and have been acknowledged worldwide. This inclusive research on silver nanoparticles has been discussed in this review to have a better understanding on the characterization of physicochemical properties, synthesis, mechanisms of action, application, safety, and limitation of AgNPs. The unique physicochemical properties of the AgNP are dependent on various parameters of AgNPs such as size, surfactant, and structure morphology of these nanoparticles. Even though there are various methods in producing AgNPs, biological method or green synthesis have high yield and biocompatibility as it uses natural agents and nontoxic chemicals. In this review, we provide an inclusive discussion on the mode of action of AgNPs that have drawn attention as antimicrobial agents covering the antibacterial and antiviral properties of AgNPs towards various types of pathogenic viruses. Topics on the safety and limitation of AgNPs were also highlighted in this review where the aggregation and cytotoxicity of these nanoparticles have becoming the main concerns of AgNP applications. Lastly, research on a better understanding in cytotoxic mechanisms of AgNPs towards the environment by breaking the technologies limit could benefit the future prospects of AgNPs.

Author Contributions: Conceptualization, M.B.F and A.W.; methodology, M.B.F. and A.S.; validation, M.B.F., E.M., and N.M.; formal analysis, A.S., R.N., and N.D.U.; investigation, A.S., R.N., and N.D.U.; resources, M.B.F. and A.W.M.; data curation, A.S., R.N., and N.D.U.; writing-original draft preparation, A.S. and M.B.F.; writing-review and editing, E.B., N.M., A.S., R.N., and N.D.U.; visualization, A.S., E.B., A.W.M., and M.B.F.; supervision, M.B.F.; project administration, A.S.; funding acquisition, M.B.F. All authors have read and agreed to the published version of the manuscript.

Funding: This research was funded by Ministry of Higher Education (Malaysia) Transdisciplinary Research Grant Scheme, TRGS/1/2019/UKM/02/1/3, in form of database subscription. The funders did not have any contribution to or decision in the publication or preparation of this manuscript.

Acknowledgments: We are grateful to Faculty of Medicine, Universiti Kebangsaan Malaysia (UKM) for providing resources to complete this review. 
Conflicts of Interest: The authors declare no conflict of interest.

\section{References}

1. Khorasani, G.; Hosseinimehr, S.J.; Azadbakht, M.; Zamani, A.; Mahdavi, M.R. Aloe versus silver sulfadiazine creams for second-degree burns: A randomized controlled study. Surg. Today 2009, 39, 587-591. [CrossRef] [PubMed]

2. Zheludkevich, M.L.; Gusakov, A.G.; Voropaev, A.G.; Vecher, A.A.; Kozyrski, E.N.; Raspopov, S.A. Oxidation of silver by atomic oxygen. Oxid. Met. 2004, 61, 39-48. [CrossRef]

3. Abou El-Nour, K.M.M.; Eftaiha, A.; Al-Warthan, A.; Ammar, R.A.A. Synthesis and applications of silver nanoparticles. Arab. J. Chem. 2010, 3, 135-140. [CrossRef]

4. Alheety, N.F.; Majeed, A.H.; Alheety, M.A. Silver nanoparticles anchored 5-methoxy benzimidazol thiomethanol (MBITM): Modulate, characterization and comparative studies on MBITM and Ag-MBITM antibacterial activities. J. Phys. Conf. Ser. 2019, 1294. [CrossRef]

5. Pourzahedi, L.; Eckelman, M.J. Comparative life cycle assessment of silver nanoparticle synthesis routes. Environ. Sci. Nano 2015, 2, 361-369. [CrossRef]

6. Pal, S.; Nisi, R.; Stoppa, M.; Licciulli, A. Silver-Functionalized bacterial cellulose as antibacterial membrane for wound-healing applications. ACS Omega 2017, 2, 3632-3639. [CrossRef]

7. Nguyen, L.; Tao, P.P.; Liu, H.; Al-Hada, M.; Amati, M.; Sezen, H.; Gregoratti, L.; Tang, Y.; House, S.D.; Tao, F.F. $X$-ray photoelectron spectroscopy studies of nanoparticles dispersed in static liquid. Langmuir 2018, 34, 9606-9616. [CrossRef]

8. Baudot, C.; Tan, C.M.; Kong, J.C. FTIR spectroscopy as a tool for nano-material characterization. Infrared Phys. Technol. 2010, 53, 434-438. [CrossRef]

9. Gorham, J.M.; MacCuspie, R.I.; Klein, K.L.; Fairbrother, D.H.; Holbrook, D. UV-induced photochemical transformations of citrate-capped silver nanoparticle suspensions. J. Nanoparticle Res. 2012, 14. [CrossRef]

10. Balaji, D.S.; Basavaraja, S.; Deshpande, R.; Mahesh, D.B.; Prabhakar, B.K.; Venkataraman, A. Extracellular biosynthesis of functionalized silver nanoparticles by strains of Cladosporium cladosporioides fungus. Colloids Surf. B Biointerfaces 2009, 68, 88-92. [CrossRef] [PubMed]

11. Chen, S.; Quan, Y.; Yu, Y.L.; Wang, J.H. Graphene quantum dot/silver nanoparticle hybrids with oxidase activities for antibacterial application. ACS Biomater. Sci. Eng. 2017, 3, 313-321. [CrossRef]

12. Zhang, H.; Zhang, C. Transport of silver nanoparticles capped with different stabilizers in water saturated porous media. J. Mater. Environ. Sci. 2014, 5, 231-236.

13. Ribeiro, M.S.; De Melo, L.S.A.; Farooq, S.; Baptista, A.; Kato, I.T.; Núñez, S.C.; De Araujo, R.E. Photodynamic inactivation assisted by localized surface plasmon resonance of silver nanoparticles: In vitro evaluation on Escherichia coli and Streptococcus mutans. Photodiagnosis Photodyn. Ther. 2018, 22, 191-196. [CrossRef] [PubMed]

14. Carlson, C.; Hussein, S.M.; Schrand, A.M.; Braydich-Stolle, L.K.; Hess, K.L.; Jones, R.L.; Schlager, J.J. Unique cellular interaction of silver nanoparticles: Size-dependent generation of reactive oxygen species. J. Phys. Chem. B 2008, 112, 13608-13619. [CrossRef] [PubMed]

15. Patra, S.; Mukherjee, S.; Barui, A.K.; Ganguly, A.; Sreedhar, B.; Patra, C.R. Green synthesis, characterization of gold and silver nanoparticles and their potential application for cancer therapeutics. Mater. Sci. Eng. C 2015, 53, 298-309. [CrossRef] [PubMed]

16. Beer, C.; Foldbjerg, R.; Hayashi, Y.; Sutherland, D.S.; Autrup, H. Toxicity of silver nanoparticles-Nanoparticle or silver ion? Toxicol. Lett. 2012, 208, 286-292. [CrossRef]

17. Hunt, P.R.; Keltner, Z.; Gao, X.; Oldenburg, S.J.; Bushana, P.; Olejnik, N.; Sprando, R.L. Bioactivity of nanosilver in Caenorhabditis elegans: Effects of size, coat, and shape. Toxicol. Rep. 2014, 1, 923-944. [CrossRef]

18. Morones, J.R.; Elechiguerra, J.L.; Camacho, A.; Holt, K.; Kouri, J.B.; Ramírez, J.T.; Yacaman, M.J. The bactericidal effect of silver nanoparticles. Nanotechnology 2005, 16, 2346-2353. [CrossRef]

19. Prakash, V.; Pawar, J.; Patel, A.K.; Henry, R.; Patwardhan, A. Analysis of Nucleation and Growth Parameter of Silver Nanoparticles for Sensors. In Proceedings of the 2017 1st International Conference on Electronics, Materials Engineering and Nano-Technology (IEMENTech), Kolkata, India, 28-29 April 2017. [CrossRef] 
20. Slepička, P.; Kasálková, N.S.; Siegel, J.; Kolská, Z.; Švorčík, V. Methods of gold and silver nanoparticles preparation. Materials 2020, 13, 1. [CrossRef]

21. Soria-Aguilar, M.D.J.; Zamarripa, G.G.; Sánchez-Castillo, M.A.; García-Cerda, L.A.; Carrillo-Pedroza, F.R. Synthesis and characterization of ag nanoparticles supported in blast furnace dust microspheres. Rev. Latinoam. de Metal. y Mater. 2018, 38, 2-8.

22. Wu, J.; Xu, Y.; Xu, P.; Pan, Z.; Chen, S.; Shen, Q.; Zhan, L.; Zhang, Y.; Ni, W. Surface-enhanced Raman scattering from AgNP-graphene-AgNP sandwiched nanostructures. Nanoscale 2015, 7, 17529-17537. [CrossRef] [PubMed]

23. Gandhewar, V.R.; Bansod, S.V.; Borade, A.B. Induction furnace-A review. Int. J. Eng. Technol. 2011, 3, 277-284.

24. Zeng, H.; Du, X.W.; Singh, S.C.; Kulinich, S.A.; Yang, S.; He, J.; Cai, W. Nanomaterials via laser ablation/irradiation in liquid: A review. Adv. Funct. Mater. 2012, 22, 1333-1353. [CrossRef]

25. Zhang, D.; Choi, W.; Jakobi, J.; Kalus, M.R.; Barcikowski, S.; Cho, S.H.; Sugioka, K. Spontaneous shape alteration and size separation of surfactant-free silver particles synthesized by laser ablation in acetone during long-period storage. Nanomaterials 2018, 8, 529. [CrossRef] [PubMed]

26. Noroozi, M.; Radiman, S.; Zakaria, A.; Soltaninejad, S. Fabrication, characterization, and thermal property evaluation of silver nanofluids. Nanoscale Res. Lett. 2014, 9, 645. [CrossRef]

27. Gasaymeh, S.S.; Radiman, S.; Heng, L.Y.; Saion, E.; Mohamed Saeed, G.H. Synthesis and characterization of silver/Polyvinilpirrolidone (AG/PVP) nanoparticles using gamma irradiation techniques. Am. J. Appl. Sci. 2010, 7, 879-888. [CrossRef]

28. Wang, H.; Qiao, X.; Chen, J.; Ding, S. Preparation of silver nanoparticles by chemical reduction method. Colloids Surf. A Physicochem. Eng. Asp. 2005, 256, 111-115. [CrossRef]

29. Shenava, A. Synthesis of silver nanoparticles by chemical reduction method and their antifungal activity. Int. Res. J. Pharm. 2013, 4, 111-113. [CrossRef]

30. Guzmán, M.G.; Dille, J.; Godet, S. Synthesis of silver nanoparticles by chemical reduction method and their antibacterial activity. Int. J. Chem. Biomol. Eng. 2009, 2, 105-111. [CrossRef]

31. Ranoszek-Soliwoda, K.; Tomaszewska, E.; Socha, E.; Krzyczmonik, P.; Ignaczak, A.; Orlowski, P.; Krzyzowska, M.; Celichowski, G.; Grobelny, J. The role of tannic acid and sodium citrate in the synthesis of silver nanoparticles. J. Nanoparticle Res. 2017, 19. [CrossRef]

32. Song, K.C.; Lee, S.M.; Park, T.S.; Lee, B.S. Preparation of colloidal silver nanoparticles by chemical reduction method. Korean J. Chem. Eng. 2009, 26, 153-155. [CrossRef]

33. Yu, D.G. Formation of colloidal silver nanoparticles stabilized by Na+-poly $(\gamma$-glutamic acid)-silver nitrate complex via chemical reduction process. Colloids Surf. B Biointerfaces 2007, 59, 171-178. [CrossRef] [PubMed]

34. Khan, Z.; Al-Thabaiti, S.A.; Obaid, A.Y.; Al-Youbi, A.O. Preparation and characterization of silver nanoparticles by chemical reduction method. Colloids Surf. B Biointerfaces 2011, 82, 513-517. [CrossRef]

35. Sileikaite, A.; Prosycevas, I.; Puiso, J.; Juraitis, A.; Guobiene, A. Analysis of silver nanoparticles produced by chemical reduction of silver salt solution. Mater. Sci. 2006, 12, 287-291.

36. Kheybari, S.; Samadi, N.; Hosseini, S.V.; Fazeli, A.; Fazeli, M.R. Synthesis and antimicrobial effects of silver nanoparticles produced by chemical reduction method. DARU 2010, 18, 168-172. [PubMed]

37. Katas, H.; Moden, N.Z.; Lim, C.S.; Celesistinus, T.; Chan, J.Y.; Ganasan, P.; Abdalla, S.S.I. Biosynthesis and potential applications of silver and gold nanoparticles and their chitosan-based nanocomposites in nanomedicine. J. Nanotechnol. 2018, 2018. [CrossRef]

38. Siddiqi, K.S.; Husen, A.; Rao, R.A.K. A review on biosynthesis of silver nanoparticles and their biocidal properties. J. Nanobiotechnology 2018, 16. [CrossRef]

39. Gudikandula, K.; Charya Maringanti, S. Synthesis of silver nanoparticles by chemical and biological methods and their antimicrobial properties. J. Exp. Nanosci. 2016, 11, 714-721. [CrossRef]

40. Fang, J.; Zhong, C.; Mu, R. The study of deposited silver particulate films by simple method for efficient SERS. Chem. Phys. Lett. 2005, 401, 271-275. [CrossRef]

41. Mukherjee, P.; Ahmad, A.; Mandal, D.; Senapati, S.; Sainkar, S.R.; Khan, M.I.; Parishcha, R.; Ajaykumar, P.V.; Alam, M.; Kumar, R.; et al. Fungus-mediated synthesis of silver nanoparticles and their immobilization in the mycelial matrix: A novel biological approach to nanoparticle synthesis. Nano Lett. 2001, 1, 515-519. [CrossRef] 
42. Vijayakumar, M.; Priya, K.; Nancy, F.T.; Noorlidah, A.; Ahmed, A.B.A. Biosynthesis, characterisation and anti-bacterial effect of plant-mediated silver nanoparticles using Artemisia nilagirica. Ind. Crops Prod. 2013, 41, 235-240. [CrossRef]

43. Kotakadi, V.S.; Rao, Y.S.; Gaddam, S.A.; Prasad, T.N.V.K.V.; Reddy, A.V.; Gopal, S.V.R.S. Simple and rapid biosynthesis of stable silver nanoparticles using dried leaves of Catharanthus roseus. Linn. G. Donn and its anti microbial activity. Colloids Surf. B Biointerfaces 2013, 105, 194-198. [CrossRef] [PubMed]

44. Vijay Kumar, P.P.N.; Pammi, S.V.N.; Kollu, P.; Satyanarayana, K.V.V.; Shameem, U. Green synthesis and characterization of silver nanoparticles using Boerhaavia diffusa plant extract and their anti bacterial activity. Ind. Crops Prod. 2014, 52, 562-566. [CrossRef]

45. De Araujo, A.R.; Ramos-Jesus, J.; De Oliveira, T.M.; De Carvalho, A.M.A.; Nunes, P.H.M.; Daboit, T.C.; Carvalho, A.P.; Barroso, M.F.; De Almeida, M.P.; Plácido, A.; et al. Identification of Eschweilenol C in derivative of Terminalia fagifolia Mart. and green synthesis of bioactive and biocompatible silver nanoparticles. Ind. Crops Prod. 2019, 137, 52-65. [CrossRef]

46. Awwad, A.M.; Salem, N.M.; Aqarbeh, M.M.; Abdulaziz, F.M. Green synthesis, characterization of silver sulfide nanoparticles and antibacterial activity evaluation. Chem. Int. 2020, 6, 42-48. [CrossRef]

47. Gupta, A.; Briffa, S.M.; Swingler, S.; Gibson, H.; Kannappan, V.; Adamus, G.; Kowalczuk, M.; Martin, C.; Radecka, I. Synthesis of silver nanoparticles using curcumin-cyclodextrins loaded into bacterial cellulose-based hydrogels for wound dressing applications. Biomacromolecules 2020. [CrossRef]

48. Vigneshwaran, N.; Ashtaputre, N.M.; Varadarajan, P.V.; Nachane, R.P.; Paralikar, K.M.; Balasubramanya, R.H. Biological synthesis of silver nanoparticles using the fungus Aspergillus flavus. Mater. Lett. 2007, 61, 1413-1418. [CrossRef]

49. Popli, D.; Anil, V.; Subramanyam, A.B.; Namratha, M.N.; Ranjitha, V.R.; Rao, S.N.; Rai, R.V.; Govindappa, M. Endophyte fungi, Cladosporium species-mediated synthesis of silver nanoparticles possessing in vitro antioxidant, anti-diabetic and anti-Alzheimer activity. Artif. Cells Nanomed. Biotechnol. 2018, 46, 676-683. [CrossRef]

50. Bharathi, V.; Nagasinduja, V.; Shahitha, S. Fungus-mediated synthesis and characterization of silver nanoparticles and its antibacterial activity against clinically isolated pathogens. Int. J. Curr. Res. Life Sci. 2018, 07, 1507-1512.

51. Pugazhenthiran, N.; Anandan, S.; Kathiravan, G.; Udaya Prakash, N.K.; Crawford, S.; Ashokkumar, M. Microbial synthesis of silver nanoparticles by Bacillus sp. J. Nanoparticle Res. 2009, 11, 1811-1815. [CrossRef]

52. Reddy, A.S.; Chen, C.Y.; Chen, C.C.; Jean, J.S.; Chen, H.R.; Tseng, M.J.; Fan, C.W.; Wang, J.C. Biological synthesis of gold and silver nanoparticles mediated by the bacteria Bacillus subtilis. J. Nanosci. Nanotechnol. 2010, 10, 6567-6574. [CrossRef] [PubMed]

53. Gurunathan, S.; Kalishwaralal, K.; Vaidyanathan, R.; Venkataraman, D.; Pandian, S.R.K.; Muniyandi, J.; Hariharan, N.; Eom, S.H. Biosynthesis, purification and characterization of silver nanoparticles using Escherichia coli. Colloids Surf. B Biointerfaces 2009, 74, 328-335. [CrossRef]

54. Prasher, P.; Singh, M.; Mudila, H. Oligodynamic effect of silver nanoparticles: A review. Bionanoscience 2018, 8, 951-962. [CrossRef]

55. Peng, S.; Chen, Y.; Jin, X.; Lu, W.; Gou, M.; Wei, X.; Xie, J. Polyimide with half encapsulated silver nanoparticles grafted ceramic composite membrane: Enhanced silver stability and lasting anti-biofouling performance. J. Memb. Sci. 2020, 611, 118340. [CrossRef]

56. Shi, Q.; Zhang, H.; Zhang, H.; Zhao, P.; Zhang, Y.; Tang, Y. Polydopamine/silver hybrid coatings on soda-lime glass spheres with controllable release ability for inhibiting biofilm formation. Sci. China Mater. 2020, 63, 842-850. [CrossRef]

57. Hajizadeh, H.; Peighambardoust, S.J.; Peighambardoust, S.H.; Peressini, D. Physical, mechanical, and antibacterial characteristics of bio-nanocomposite films loaded with Ag-modified $\mathrm{SiO} 2$ and $\mathrm{TiO} 2$ nanoparticles. J. Food Sci. 2020, 85, 1193-1202. [CrossRef]

58. Akhavan, O.; Ghaderi, E. Cu and $\mathrm{CuO}$ nanoparticles immobilized by silica thin films as antibacterial materials and photocatalysts. Surf. Coat. Technol. 2010, 205, 219-223. [CrossRef]

59. Slavin, Y.N.; Asnis, J.; Häfeli, U.O.; Bach, H. Metal nanoparticles: Understanding the mechanisms behind antibacterial activity. J. Nanobiotechnology 2017, 15, 1-20. [CrossRef] 
60. Li, X.; Robinson, S.M.; Gupta, A.; Saha, K.; Jiang, Z.; Moyano, D.F.; Sahar, A.; Riley, M.A.; Rotello, V.M. Functional gold nanoparticles as potent antimicrobial agents against multi-drug-resistant bacteria. ACS Nano 2014, 8, 10682-10686. [CrossRef]

61. Rai, M.; Deshmukh, S.D.; Ingle, A.P.; Gupta, I.R.; Galdiero, M.; Galdiero, S. Metal nanoparticles: The protective nanoshield against virus infection. Crit. Rev. Microbiol. 2016, 42, 46-56. [CrossRef]

62. Kędziora, A.; Speruda, M.; Krzyżewska, E.; Rybka, J.; Łukowiak, A.; Bugla-Płoskońska, G. Similarities and differences between silver ions and silver in nanoforms as antibacterial agents. Int. J. Mol. Sci. 2018, $19,444$. [CrossRef] [PubMed]

63. Dakal, T.C.; Kumar, A.; Majumdar, R.S.; Yadav, V. Mechanistic basis of antimicrobial actions of silver nanoparticles. Front. Microbiol. 2016, 7, 1-17. [CrossRef] [PubMed]

64. Choi, O.; Yu, C.P.; Esteban Fernández, G.; Hu, Z. Interactions of nanosilver with Escherichia coli cells in planktonic and biofilm cultures. Water Res. 2010, 44, 6095-6103. [CrossRef] [PubMed]

65. Abdalla, S.S.I.; Katas, H.; Chan, J.Y.; Ganasan, P.; Azmi, F.; Mh Busra, M.F. Antimicrobial activity of multifaceted lactoferrin or graphene oxide functionalized silver nanocomposites biosynthesized using mushroom waste and chitosan. RSC Adv. 2020, 10, 4969-4983. [CrossRef]

66. Wakshlak, R.B.K.; Pedahzur, R.; Avnir, D. Antibacterial activity of silver-killed bacteria: The "zombies" effect. Sci. Rep. 2015, 5, 1-5. [CrossRef]

67. Vazquez-Muñoz, R.; Meza-Villezcas, A.; Fournier, P.G.J.; Soria-Castro, E.; Juarez-Moreno, K.; Gallego-Hernández, A.L.; Bogdanchikova, N.; Vazquez-Duhalt, R.; Huerta-Saquero, A. Enhancement of antibiotics antimicrobial activity due to the silver nanoparticles impact on the cell membrane. PLoS ONE 2019, 14, 1-18. [CrossRef]

68. Li, W.R.; Xie, X.B.; Shi, Q.S.; Zeng, H.Y.; Ou-Yang, Y.S.; Chen, Y. Ben Antibacterial activity and mechanism of silver nanoparticles on Escherichia coli. Appl. Microbiol. Biotechnol. 2010, 85, 1115-1122. [CrossRef]

69. Katas, H.; Raja, M.A.G.; Lam, K.L. Development of chitosan nanoparticles as a stable drug delivery system for protein/siRNA. Int. J. Biomater. 2013, 2013, 1-9. [CrossRef]

70. Hu, S.; Yi, T.; Huang, Z.; Liu, B.; Wang, J.; Yi, X.; Liu, J. Etching silver nanoparticles using DNA. Mater. Horiz. 2019, 6, 155-159. [CrossRef]

71. Sadoon, A.A.; Khadka, P.; Freeland, J.; Gundampati, R.K.; Manso, R.H.; Ruiz, M.; Krishnamurthi, V.R.; Thallapuranam, S.K.; Chen, J.; Wang, Y. Silver ions caused faster diffusive dynamics of histone-like nucleoid-structuring proteins in live bacteria. Appl. Environ. Microbiol. 2020, 86, 1-16. [CrossRef]

72. Qing, Y.; Cheng, L.; Li, R.; Liu, G.; Zhang, Y.; Tang, X.; Wang, J.; Liu, H.; Qin, Y. Potential antibacterial mechanism of silver nanoparticles and the optimization of orthopedic implants by advanced modification technologies. Int. J. Nanomed. 2018, 13, 3311-3327. [CrossRef] [PubMed]

73. Song, Z.; Wu, Y.; Wang, H.; Han, H. Synergistic antibacterial effects of curcumin modified silver nanoparticles through ROS-mediated pathways. Mater. Sci. Eng. C 2019, 99, 255-263. [CrossRef] [PubMed]

74. Zhang, L.; Wu, L.; Mi, Y.; Si, Y. Silver nanoparticles induced cell apoptosis, membrane damage of azotobacter vinelandii and nitrosomonas europaea via generation of reactive oxygen species. Bull. Environ. Contam. Toxicol. 2019, 103, 181-186. [CrossRef] [PubMed]

75. Pramanik, S.; Chatterjee, S.; Saha, A.; Devi, P.S.; Suresh Kumar, G. Unraveling the interaction of silver nanoparticles with mammalian and bacterial DNA. J. Phys. Chem. B 2016, 120, 5313-5324. [CrossRef] [PubMed]

76. Jena, P.; Bhattacharya, M.; Bhattacharjee, G.; Satpati, B.; Mukherjee, P.; Senapati, D.; Srinivasan, R. Bimetallic gold-silver nanoparticles mediate bacterial killing by disrupting the actin cytoskeleton MreB. Nanoscale 2020, 12, 3731-3749. [CrossRef]

77. Kora, A.J.; Arunachalam, J. Assessment of antibacterial activity of silver nanoparticles on Pseudomonas aeruginosa and its mechanism of action. World J. Microbiol. Biotechnol. 2011, 27, 1209-1216. [CrossRef]

78. Radzig, M.A.; Nadtochenko, V.A.; Koksharova, O.A.; Kiwi, J.; Lipasova, V.A.; Khmel, I.A. Antibacterial effects of silver nanoparticles on gram-negative bacteria: Influence on the growth and biofilms formation, mechanisms of action. Colloids Surf. B Biointerfaces 2013, 102, 300-306. [CrossRef]

79. Ji, H.; Zhou, S.; Fu, Y.; Wang, Y.; Mi, J.; Lu, T.; Wang, X.; Lü, C. Size-controllable preparation and antibacterial mechanism of thermo-responsive copolymer-stabilized silver nanoparticles with high antimicrobial activity. Mater. Sci. Eng. C 2020, 110, 110735. [CrossRef] 
80. Zhou, Y.; Kong, Y.; Kundu, S.; Cirillo, J.D.; Liang, H. Antibacterial activities of gold and silver nanoparticles against Escherichia coli and bacillus Calmette-Guérin. J. Nanobiotechnology 2012, 10, 1-9. [CrossRef]

81. Das, B.; Dash, S.K.; Mandal, D.; Ghosh, T.; Chattopadhyay, S.; Tripathy, S.; Das, S.; Dey, S.K.; Das, D.; Roy, S. Green synthesized silver nanoparticles destroy multidrug resistant bacteria via reactive oxygen species mediated membrane damage. Arab. J. Chem. 2017, 10, 862-876. [CrossRef]

82. Ouda, S.M. Some nanoparticles effects on Proteus sp. and Klebsiella sp. isolated from water. Am. J. Infect. Dis. Microbiol. 2014, 2, 4-10. [CrossRef]

83. Adeyemi, O.S.; Shittu, E.O.; Akpor, O.B.; Rotimi, D.; Batiha, G.E.S. Silver nanoparticles restrict microbial growth by promoting oxidative stress and DNA damage. EXCLI J. 2020, 19, 492-500. [CrossRef] [PubMed]

84. Orlowski, P.; Tomaszewska, E.; Gniadek, M.; Baska, P.; Nowakowska, J.; Sokolowska, J.; Nowak, Z.; Donten, M.; Celichowski, G.; Grobelny, J.; et al. Tannic acid modified silver nanoparticles show antiviral activity in herpes simplex virus type 2 infection. PLOS ONE 2014, 9, 1-15. [CrossRef]

85. Park, S.J.; Park, H.H.; Kim, S.Y.; Kim, S.J.; Woo, K.; Ko, G.P. Antiviral properties of silver nanoparticles on a magnetic hybrid colloid. Appl. Environ. Microbiol. 2014, 80, 2343-2350. [CrossRef] [PubMed]

86. Gaikwad, S.; Ingle, A.; Gade, A.; Rai, M.; Falanga, A.; Incoronato, N.; Russo, L.; Galdiero, S.; Galdiero, M. Antiviral activity of mycosynthesized silver nanoparticles against herpes simplex virus and human parainfluenza virus type 3. Int. J. Nanomed. 2013, 8, 4303-4314. [CrossRef]

87. Lara, H.H.; Ayala-Nuñez, N.V.; Ixtepan-Turrent, L.; Rodriguez-Padilla, C. Mode of antiviral action of silver nanoparticles against HIV-1. J. Nanobiotechnology 2010, 8, 1-10. [CrossRef]

88. Mori, Y.; Ono, T.; Miyahira, Y.; Nguyen, V.Q.; Matsui, T.; Ishihara, M. Antiviral activity of silver nanoparticle/chitosan composites against H1N1 influenza A virus. Nanoscale Res. Lett. 2013, 8, 93. [CrossRef]

89. Huy, T.Q.; Hien Thanh, N.T.; Thuy, N.T.; Van Chung, P.; Hung, P.N.; Le, A.T.; Hong Hanh, N.T. Cytotoxicity and antiviral activity of electrochemical - synthesized silver nanoparticles against poliovirus. J. Virol. Methods 2017, 241, 52-57. [CrossRef]

90. Morris, D.; Ansar, M.; Speshock, J.; Ivanciuc, T.; Qu, Y.; Casola, A.; Garofalo, R. Antiviral and immunomodulatory activity of silver nanoparticles in experimental rsv infection. Viruses 2019, 11, 732. [CrossRef]

91. Lu, L.; Sun, R.W.-Y.; Chen, R.; Hui, C.-K.; Ho, C.-M.; Luk, J.M.; Lau, G.K.K.; Che, C.-M. Silver nanoparticles inhibit hepatitis B virus replication. Antivir. Ther. 2008, 13, 253-262.

92. Chen, N.; Zheng, Y.; Yin, J.; Li, X.; Zheng, C. Inhibitory effects of silver nanoparticles against adenovirus type 3 in vitro. J. Virol. Methods 2013, 193, 470-477. [CrossRef] [PubMed]

93. Ren, H.; Fu, K.; Mu, C.; Zhen, X.; Wang, G. L166P mutant DJ-1 promotes cell death by dissociating Bax from mitochondrial Bcl-XL. Mol. Neurodegener. 2012, 7, 1-11. [CrossRef] [PubMed]

94. Lv, X.; Wang, P.; Bai, R.; Cong, Y.; Suo, S.; Ren, X.; Chen, C. Inhibitory effect of silver nanomaterials on transmissible virus-induced host cell infections. Biomaterials 2014, 35, 4195-4203. [CrossRef] [PubMed]

95. Shereen, M.A.; Khan, S.; Kazmi, A.; Bashir, N.; Siddique, R. COVID-19 infection: Origin, transmission, and characteristics of human coronaviruses. J. Adv. Res. 2020, 24, 91-98. [CrossRef]

96. Sarkar, D.S. Silver nanoparticles with bronchodilators through nebulisation to treat COVID 19 patients. J. Curr. Med. Res. Opin. 2020, 3, 449-450. [CrossRef]

97. Jia, M.; Zhang, W.; He, T.; Shu, M.; Deng, J.; Wang, J.; Li, W.; Bai, J.; Lin, Q.; Luo, F.; et al. Evaluation of the genotoxic and oxidative damage potential of silver nanoparticles in human NCM460 and HCT116 cells. Int. J. Mol. Sci. 2020, 21, 1618. [CrossRef]

98. El-Shishtawy, R.M.; Asiri, A.M.; Abdelwahed, N.A.M.; Al-Otaibi, M.M. In situ production of silver nanoparticle on cotton fabric and its antimicrobial evaluation. Cellulose 2011, 18, 75-82. [CrossRef]

99. Gupta, A.; Low, W.L.; Radecka, I.; Britland, S.T.; Mohd Amin, M.C.I.; Martin, C. Characterisation and in vitro antimicrobial activity of biosynthetic silver-loaded bacterial cellulose hydrogels. J. Microencapsul. 2016, 33, 725-734. [CrossRef]

100. Wu, J.; Zheng, Y.; Song, W.; Luan, J.; Wen, X.; Wu, Z.; Chen, X.; Wang, Q.; Guo, S. In situ synthesis of silver-nanoparticles/bacterial cellulose composites for slow-released antimicrobial wound dressing. Carbohydr. Polym. 2014, 102, 762-771. [CrossRef]

101. Quaroni, L.; Chumanov, G. Preparation of Polymer-coated functionalized silver nanoparticles. J. Am. Chem. Soc. 1999, 121, 10642-10643. [CrossRef] 
102. Hajtuch, J.; Hante, N.; Tomczyk, E.; Wojcik, M.; Radomski, M.W.; Santos-Martinez, M.J.; Inkielewicz-Stepniak, I. Effects of functionalized silver nanoparticles on aggregation of human blood platelets. Int. J. Nanomed. 2019, 14, 7399-7417. [CrossRef]

103. Dowling, D.P.; Betts, A.J.; Pope, C.; McConnell, M.L.; Eloy, R.; Arnaud, M.N. Anti-bacterial silver coatings exhibiting enhanced activity through the addition of platinum. Surf. Coat. Technol. 2003, 163-164, 637-640. [CrossRef]

104. Sedira, S.; Ayachi, A.A.; Lakehal, S.; Fateh, M.; Achour, S. Silver nanoparticles in combination with acetic acid and zinc oxide quantum dots for antibacterial activities improvement-A comparative study. Appl. Surf. Sci. 2014, 311, 659-665. [CrossRef]

105. Balamurugan, A.; Balossier, G.; Laurent-Maquin, D.; Pina, S.; Rebelo, A.H.S.; Faure, J.; Ferreira, J.M.F. An in vitro biological and anti-bacterial study on a sol-gel derived silver-incorporated bioglass system. Dent. Mater. 2008, 24, 1343-1351. [CrossRef]

106. Calderón-Jiménez, B.; Johnson, M.E.; Montoro Bustos, A.R.; Murphy, K.E.; Winchester, M.R.; Baudrit, J.R.V. Silver nanoparticles: Technological advances, societal impacts, and metrological challenges. Front. Chem. 2017, 5, 1-26. [CrossRef] [PubMed]

107. Mao, B.H.; Chen, Z.Y.; Wang, Y.J.; Yan, S.J. Silver nanoparticles have lethal and sublethal adverse effects on development and longevity by inducing ROS-mediated stress responses. Sci. Rep. 2018, 8, 1-16. [CrossRef]

108. Kwon, H.B.; Lee, J.H.; Lee, S.H.; Lee, A.Y.; Choi, J.S.; Ahn, Y.S. A case of argyria following colloidal silver ingestion. Ann. Dermatol. 2009, 21, 308-310. [CrossRef]

109. Xu, J.Y.; Zhang, H. Long-term effects of sliver nanoparticles on the abundance and activity of soil microbiome. J. Environ. Sci. (China) 2018, 69, 3-4. [CrossRef]

110. Lok, C.N.; Ho, C.M.; Chen, R.; He, Q.Y.; Yu, W.Y.; Sun, H.; Tam, P.K.H.; Chiu, J.F.; Che, C.M. Silver nanoparticles: Partial oxidation and antibacterial activities. J. Biol. Inorg. Chem. 2007, 12, 527-534. [CrossRef]

111. Menazea, A.A. Femtosecond laser ablation-assisted synthesis of silver nanoparticles in organic and inorganic liquids medium and their antibacterial efficiency. Radiat. Phys. Chem. 2020, 168, 108616. [CrossRef]

(C) 2020 by the authors. Licensee MDPI, Basel, Switzerland. This article is an open access article distributed under the terms and conditions of the Creative Commons Attribution (CC BY) license (http://creativecommons.org/licenses/by/4.0/). 